\title{
Architectural qualities of Danish office buildings built between 1960 and 1980, seen in a contemporary sustainable perspective
}

\author{
L. Hannoudi ${ }^{1}$, M. Lauring ${ }^{1} \&$ J. Christensen ${ }^{2}$ \\ ${ }^{1}$ Department of Architecture, Design and Media Technology, \\ Aalborg University, Denmark \\ ${ }^{2}$ Technical University of Denmark, Denmark
}

\begin{abstract}
This study is about evaluating the past and present architectural quality of office buildings built between 1960 and 1980 in Denmark. The evaluation will focus on the expression of these buildings in relation to their context, combined with the present sustainable performance of the buildings and their critical problems.

The initial method is a historical study to define the originally intended architectural quality of the office buildings and the different aspects related to this quality. The architectural quality is studied in relation to the societal and technological processes that characterized this period, with special focus on industrialization and its impact on the design process, particularly in adopting rational and economic solutions.

When evaluating the buildings in a contemporary, sustainable perspective, the designer faces many problems. These include: economic problems due to high energy consumption; comfort problems due to bad indoor climate; and environmental problems due to the use of construction materials with a negative impact on the environment. Site visits show that these buildings are facing many characteristic constructional and aesthetic problems regarding material durability, mould and fungus, and lack of tightness.

The analysis of the originally intended architectural quality combined with current constructional, sustainable and aesthetic evaluation forms the basis for a discussion on the possibilities of implementing sustainable solutions in the office
\end{abstract}


buildings. This implementation will have an impact on the aesthetic output, and the concepts of possible contemporary architectures are highlighted.

Keywords: architectural quality, sustainable performance, modernism, industrialization, environment, aesthetic aspects, economic, comfort problems, durability and rationality.

\section{Introduction}

Denmark witnessed a significant shift in the approach to building construction in the sixties and the seventies of the last century. This was due to broad developments, both in industry generally and in the building sector in particular.

During this period, due to the high demand, a large number of office buildings were built. Industrialization of the building process was a solution to meet the high demand because of the economic benefits and the reduced need for bricklayers of which there were shortage. These office buildings came to face many problems later on, especially regarding high energy consumption and the high number of overheating hours. The Danish government has announced a strategy for renovation of buildings in Denmark, and it is significant that a large portion of building renovation in the country will be implemented on buildings constructed in the abovementioned period. The long-term strategy is that the energy consumption of buildings from 2050 should depend on renewable energy (Ministry of Buildings Energy agency [1]).

This paper will study these office buildings through analysing their architectural qualities. The focus will be on the impact of industrialization on the architectural quality of the buildings. An assessment of the technical performance of the office buildings will be achieved combined with an aesthetic evaluation.

\section{Method}

The paper starts with literary research on the history and development of architecture in Denmark in general and with focus on the period between 1960 and 1980. This is followed by conducting relevant research on defining the meaning of 'architectural quality' in the building sector, and studying the different aspects related to this quality like economic, functional, aesthetic and environmental aspects. These aspects are analysed for office buildings with focus on what were originally intended in the 1960s and 1970s, and subsequently how these qualities are being considered today in a sustainable perspective. This is combined with literary studies of the different technological processes that characterize the period, especially industrialization and its impact on the design process and building construction. Qualitative research is then carried out through making interviews with different architectural firms and through site visits to documents in photos some of the problems in the aforementioned buildings. 


\section{Historical background}

Modern architecture evolved less than a century ago to reconcile an idealized vision of society with the force of Industrial Revolution. The task, then, was to rediscover the true path of architecture to unearth forms suited to the needs and aspirations of modern industrial societies, and to create images capable of embodying the ideals of the supposedly distinct "modern age" (Curtis [2]).

After the Second World War, a higher degree of industrialization was necessary in Denmark to meet the expected expansion in all sectors of society, both public and private. This was in keeping with the ideology of functionalism as explained in the books of Dirckinck-Holmfeld [3]. Industrialization was one of the main prerequisites for the considerable increase in building construction. Many advantages were gained through the industrialization of building components, for example reductions in building cost and the reduced need for bricklayers. But at the same time there were many problems regarding the quality of the construction that now need to be solved through renovation (Flagstad and Laustsen [4]).

The 'landscape office' as type began to get used in Denmark at the start of the 1960s. This type of office room was meant to be the ideal physical form for an office. The designers tried to utilize the rational advantages of the large office space and reduce the disadvantages of it (Flagstad and Laustsen [4]).

The energy crisis in 1973-74 and the subsequent Building Regulations of 1977 increased the demand for improved insulation and generally better thermal design of office buildings. This meant that new buildings became tighter and the windows relatively small. This action created problems with regard to indoor climate, for example reduced daylight and ventilation (Hindrup et al. [5]).

In Denmark, the focus on energy efficient buildings is now great, and the building industry is set to play an important role in the ambition of becoming completely fossil-free by 2050 . Low-energy building solutions have been a focus area in Denmark since the oil crisis of the 1970s, which has helped the country develop unique expertise within the sustainable construction sector (Mortensen et al. [6]).

\section{Quality in the building sector}

This section describes qualitative research undertaken to define the meaning of architectural quality in the building sector. Quality in the building sector may have two meanings: firstly, quality in terms of an industrial production perspective, and secondly, quality that is defined according to the architectural design and urban planning point of view (architectural quality). Where the first comes from a wish to limit the faults and weaknesses in an industrial product, architectural quality refers to more general interests. Architectural quality can be divided into three general quality parameters: property; values; and connection between the different properties and values (Beim et al. [7]).

Property in the building sector is characterized by different sub-elements and the way in which they perform. Value is a relative quality which is added to the architectural work through users and their backgrounds in historical, cultural, 
social and economical contexts. If the property fulfil the user's needs, wishes and normative principles, a good connection is obtained. The connection is radical quality that works in binding the architectural work together in one composition, where sub elements and their properties work together in a higher level (Beim et al. [7].

\section{The architectural quality of office buildings in Denmark between 1960 and 1980}

Architectural quality will be discussed according to the definitions above in terms of the following aspects: property, values and the connections between the different properties and values.

\subsection{Properties}

Through the period between 1960 and 1980, many new materials saw the light of day. New methods for wood preservation were developed, along with different types of roof and facade cladding materials. A new term, 'maintenance free materials', appeared, which meant that building components could remain for a long period without maintenance. This seemed an advantage when introduced, but later on problems emerged (Dragheim [8]).

In this period, concrete was used in many buildings as a facade material, and it was thought to be a durable material. However, later it was shown that it was prone to cracking and the steel reinforcement to rust. The result was discoloration and in many situations the bearing elements were weakened and needed repairing (Dragheim [8]). Due to using different components in the facade, there was a need to use sealing materials and techniques between them. Not all of these materials showed long-term durability, and there were many problems regarding water and wind tightness. Many types of wood used were of low quality and the wood wasn't impregnated properly, which led to some parts, such as window frames, rotting within a short time (Dragheim [8]).

The thermal and optical properties of different building components were much different than those available now. According to the 1961 Building Regulations, the maximum heat transfer coefficient for an external wall brick was approximately $0.99 \mathrm{~W} / \mathrm{m}^{2} \mathrm{~K}$ (Ministry of Housing [9]). The maximum heat transfer coefficient of the same component according to building regulations in 2015 is $0.3 \mathrm{~W} / \mathrm{m}^{2} \mathrm{~K}$ (Energy Agency [10]). The thickness of insulation in building construction in the sixties was low, sometimes as little as $30 \mathrm{~mm}$, while today it can reach $190 \mathrm{~mm}$ or more. In some cases in the 1960s, the insulation consisted of small pieces placed randomly (Dragheim [8]). The high heat transfer coefficient combined with low thickness installed is the reason for high energy consumption for heating.

Windows, in the 1961 building regulations, should consist of two layers of glazing with a minimum distance of $12 \mathrm{~mm}$ between them (Ministry of Housing [9]). The approximate heat transfer coefficient of the glazing part is $2.9 \mathrm{~W} / \mathrm{m}^{2} \mathrm{~K}$, which is much higher than heat transfer coefficient of a modern energy efficient 
window, which is about $0.6 \mathrm{~W} / \mathrm{m}^{2} \mathrm{~K}$ (three layers glazing with argon and low emission coating) (Secretariat of Energy Labelling [11]). The light transmittance and heat gain of two-layer glazing are 0.82 and 0.76 , respectively. The light transmittance is a little higher than for an energy window, but there are still a lot of issues regarding lack of daylight in office buildings built in the sixties. The reason is errors in the design of office rooms, for example having big depth in office landscape rooms, or using small windows.

The heat transfer coefficient of external walls and windows in the Danish Building Regulations 1966 is almost the same as in the Building Regulations 1961. The same is true for the Building Regulations 1972, with small changes regarding the windows (Ministry of Housing [9]).

Due to the energy crisis of 1973, a new and very stringent set of Building Regulations was introduced in 1977, with demands for much better insulation of new constructions. Regarding the thermal conductivity of insulation used in the period between 1960 and 1980, it can be said in general that the prevailing lambda values in the period were $0.045,0.042$ and $0.039 \mathrm{~W} / \mathrm{mK}$ (Gram [12]). The lambda value was a little high compared to that of the materials used today, which is 0.040 to $0.030 \mathrm{~W} / \mathrm{mK}$.

Most of the problems that face office buildings that were built between 1960 and 1980 are related to the external envelope, while the internal part of the building has shown good durability (Dragheim [8]). The external envelope faces problems regarding its energy efficiency and durability due to the types of materials used.

\subsection{Values}

Values are defined by the users and the community as a larger context and depend on the properties of the different components, how they are connected and how they work together to achieve the aim of the building. Below is an explanation of the values related to office buildings built between 1960 and 1980 .

\subsubsection{Economic}

In the industrialization process, there was no intention of making architecture a symbol of capitalism; the goal was to have a classless architecture, an architecture based on rationalization and on technology [3]. Industrialization, by using prefabricated elements, helped greatly to reduce the cost of building construction. Producing different building components in a factory and then assembling them at the construction site enabled a shorter construction time, which had an effect on the total cost of the building.

The client had to pay a lot of expenses to cover his occupancy and when the construction is economically efficient, the rent paid by the client will be less. Similarly, when the building is energy efficient this will affect the cost of heating, lighting and ventilating the office. From 1960 to 1973 oil prices were in general very low and running costs for heating, lighting and ventilation were not of great importance. This changed with the oil crises of 1973 and 1979.

\subsubsection{Functional}

One of the developments in the design of office buildings was concerned with office landscaping, emphasizing, for example, improved patterns of 
communications. It was important to trace the flow of work before the layout of office desks or departments could be successfully designed (Duffy et al. [13]).

An argument for an easy-going, participative management style was that functional relationships matter more than hierarchical links (Duffy et al. [13]). An appropriate layout for this could be found in landscape office buildings and this was expected to have an influence on increasing productivity and the effectiveness of the work.

The concept of office landscaping provided organized, multipurpose areas, based on arguments such as transparency and clarity of working processes, and development of group spirit. Working together in one big office room might help effective cooperation between the workers who constantly exchanged information, which would help to create a good atmosphere between them and would be reflected in the productivity of the company (Ernst Neufert [14]).

The new materials proposed for use in the facades, such as glass and curtain walls, supported the thesis of the open plan office because of the possibility of positioning the partition anywhere on the facade, according to window mullions.

Working in an open office room might also have some disadvantages as it later occurred, such as reduced privacy for the workers and especially noise from other workers in the same open office room.

\subsubsection{Comfort}

The energy crisis in 1973-74 and the 1977 regulations meant improved tightness of office rooms and specified that windows should be relatively small. This action created problems regarding indoor climate, for example reduced daylight and ventilation problems (Hindrup et al. [5]).

Multi-storey office buildings in Denmark face different problems regarding indoor climate. One problem may be due to the installation of a lot of IT equipment in the office which has increased dramatically thus increasing problems with overheating hours in the office room. Windows can be the reason for some problems, especially related to the indoor climate, like solar radiation, cold drafts and leakage (Danish Working Environment Authority [15]).

\subsubsection{Environment}

In 1960, pressure impregnation was introduced for the impregnation of wood for building construction in Denmark. This material was used until the Environmental Protection Act of 1974. There was not much attention to or control over the use of these materials in the sixties (Abildgaard [16]). This means that it is possible that the wood used for facade cladding for office buildings built in the sixties was treated with chemical substances such as arsenic. This wood remains a problem in relation to disposal or recycling.

A large number of facade claddings of office buildings built between 1960 and 1980 contain asbestos or similar materials that can be hazardous for human health and the environment (Dragheim [8]). When facades need to be renovated, there is a problem in recycling and/or treating these materials. 


\subsubsection{Aesthetic}

A building expresses many things through its appearance; it expresses the social and economic priorities which are applicable in the community. It expresses the technical systems and the function(s) of the building. Other unique things which are expressed in the building are locality, prosperity and craftsmanship (Anne Beim [17]). The facades of the office buildings that were built between 1960 and 1980 are typically facades of detached buildings, physically independent of other buildings, and may or may not relate to the surrounding context.

Continuity in the context of facade is defined by several considerations, such as continuity in the history and tradition of the facade or continuity in surfaces together with streets (Plante [18]). The new architectural design of office buildings built in the sixties and seventies reflected what was considered a new era, for example new lifestyle or modern building technology. The Modern Movement distanced itself from the images of the past through clear, clean, flat, sharp, and edgy facades designed to establish the new architectural order. Another aspect of continuity that was brought up by the Modern Movement was continuity between inside and outside, implemented by creating a continuity of the flowing space through an ephemeral, skin-like curtain wall. On the modern facade, continuity was expressed by panels mostly made of glass or other light materials and the enclosure of the interior space disappears through the transparent facade.

Regarding continuity of surface and street, the office buildings built in the sixties and the seventies may have 4-6 floors in inner cities. The height in most cases is close to that of the surrounding buildings and the facades are relatively uniform, which creates a strong enclosure in the street.

The office buildings that were built between 1960 and 1980 used prefabricated elements as a rational and economical solution. These prefabricated systems also had their influence on the style and expression. The intensive use of concrete in the whole facade, or in conjunction with other materials, gave the facade a white or light-coloured look, which was dominating on the facade. The use of prefabricated elements in most of the office buildings gave the facade an expression of monotony, high degree of similarity between buildings and a lack of individual identity (Dragheim [8]).

Regularity introduced rhythm and repetition that were achieved by standardized elements and modular coordination. The repetition of similar elements in the facades of the office buildings was noticed in many cases. In some cases, the repetition can, with the help of other effects like shadows, give the facade an interesting pattern that changes with the movement of the shadows through the day.

Different structural systems were used in this period, for instance beams and columns or transverse bearing walls. This had its influence on facades that featured horizontal lines and no holes in the facades and which bear only their own weight. Many facades are made of light constructions with continuous window strips and parapets, preferably based on fibre cement plate (Dragheim [8)]. The new facade components, such as curtain walls and glass, have aesthetic qualities which are expressed through the concept of surface of volume. The aesthetic principle of 


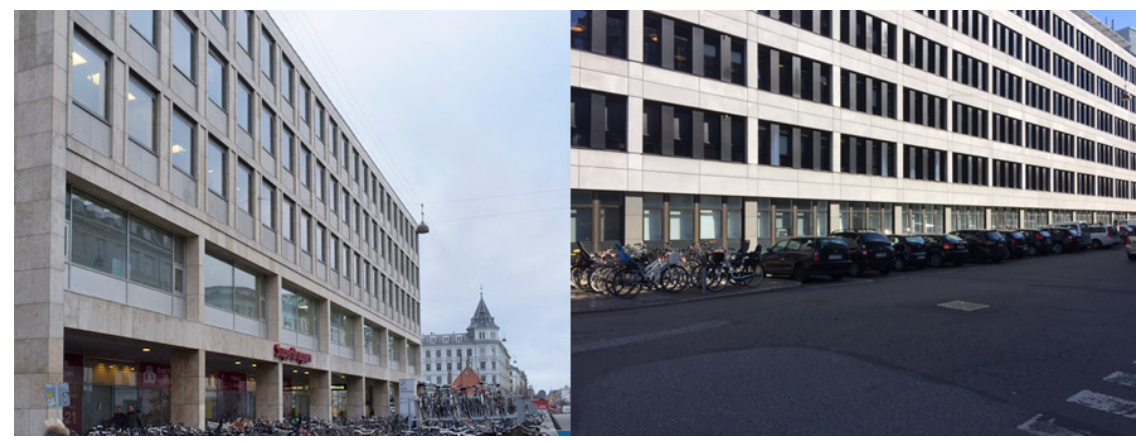

Figure 1: Concrete facades will often be dominated by white or light grey colours.
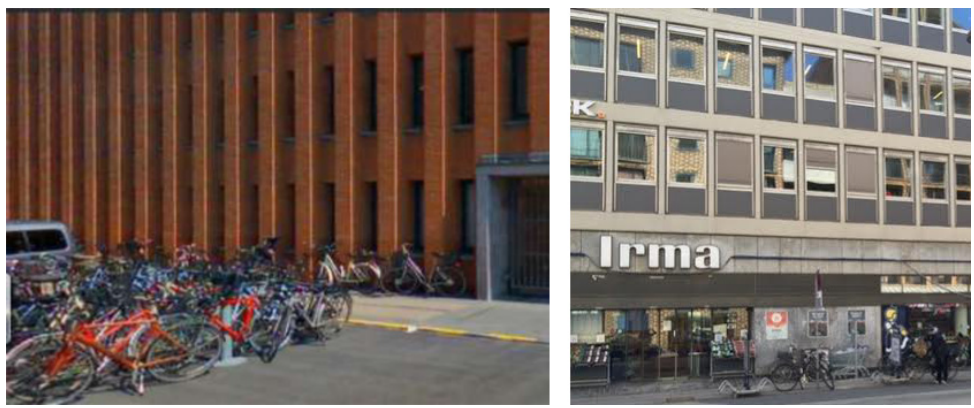

Figure 2: The repetition of similar squared or vertical elements of the facades.

surface of volume has been derived from the fact that such architecture has no solid supporting facade walls.

The architectural expression of that period was contrary to traditional Danish buildings. There was the use of horizontal roofs by using several layers of roofing felt [19]. This has a large influence on the building facade expression. The old types of buildings roof were like pitched roof, shed roof and mansard roof [19].

There was a focus on the intrinsic elegance of many materials such as aluminium, glass, and concrete, excluding all kinds of decoration with a preference for machine-made architectural details created by new technologies. The mostused materials for facade cladding are fibre cement plates, aluminium plates, steel, pressed mineral wool and glass fibre plates. Heavy materials like bricks were used only exceptionally (Dragheim [8]).

Generally, most of the prefabricated office buildings of the sixties and seventies were without their own identity as outstanding or spectacular buildings. In the following decades companies have started to have several demands regarding how the building should reflect the image and the culture of the company. The tendency has moved towards 'built to suit'. With 'built to suit' the company, through the design, can influence the signals that the building sends out. The property companies, contractors and architects try hard to fulfil these needs despite the 


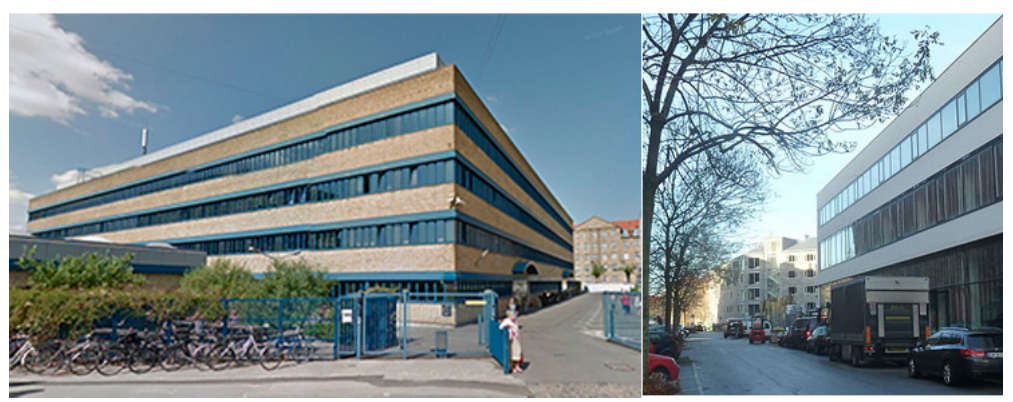

Figure 3: The dominating horizontal lines in some of the facades.
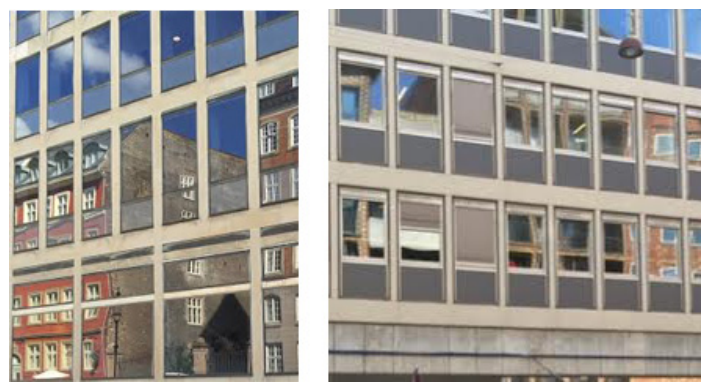

Figure 4: $\quad$ Some of the new cladding materials like metal and dark glass.

buildings generally having a traditional prefabricated building as a base, trying to achieve the demands of the companies through different facade solutions (Garre [20]).

\subsection{Connection between the different properties and values}

The connection between the different components' properties, values and criteria is a radical quality that works in binding the architectural work together holistically, where building components and their properties work together at a higher level. This connection is achieved through an industrialized system that takes into consideration different aspects and parameters and how to integrate them together in a holistic work. Industrialization is a generic method of organization based on quantity and offering finished products (Zabihi et al. [21]).

There are a number of technical criteria for this industrialized process that can be summarized as: Modular Coordination based on arbitrary dimensions for establishing the position of structural elements and for defining the size and of these elements, Standardization, which is required for the use of prefabricated building avoid the errors that can happen when choosing the building components, Limitation of Components, which requested the repetition of basic dimensions. The advantage of the limitation of components is the high degree of standardization of information, prefabrication or fabrication in advance, is to 
produce building components for immediate or later use and assembly on a building site (Plante [18]).

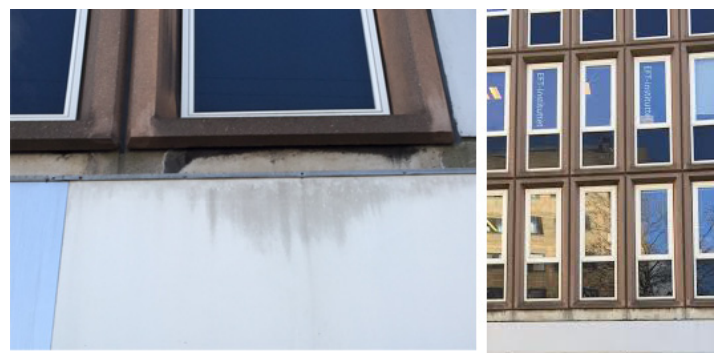

Figure 5: $\quad$ Problems like mould in the facade.
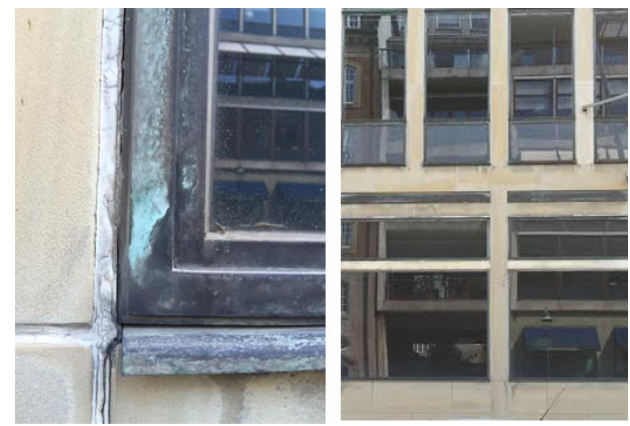

Figure 6: Problems in sealing materials in some parts of the facades.

There was a great need for industrialized building components for the construction of office buildings in the sixties and the seventies due to the large demand for office buildings in that period. There were many economic benefits and time savings with this new system, but there were also many characteristic problems that faced the office buildings later on, such as cracks in the concrete carbonates and corrosion of the reinforcements. Some parts of the facades faced problems like mould and fungus, and there were problems with sealing materials (Dragheim [8]).

\section{Discussion}

The architectural quality of office buildings in Denmark between 1960 and 1980 has been analysed through a focus on the physical properties, the user-defined values of the buildings and the connecting system between the properties and values. Then the architectural quality has been evaluated in a contemporary perspective. Analyzing and evaluating the architectural quality has been achieved through literature study, site visits and interviews. 
Analyzing the thermal and optical properties of different building materials and components, shows that they differ a lot compared to the properties defined in Building Regulation 2010 and 2015.

Analyzing the architectural values that are defined by the user and the community, as a larger context, shows many problems in these buildings. In the economic issues, Industrialization, by using prefabricated elements, helped greatly to reduce the cost of building construction. But when the building is not energy efficient this has an effect on increasing the cost of heating, lighting and ventilation. In the functional aspects, the office landscaping, has emphasised, for example, improved patterns of communications, but working in an open office room might also have some disadvantages, such as reduced privacy for the workers and especially noise from other workers in the same open office room. Regarding indoor climate and comfort there are increasing problems with overheating hours in the office room and also reduced daylight and ventilation problems. Regarding environmental issues, a large number of facade claddings of office buildings built between 1960 and 1980 contain asbestos or similar materials that can be hazardous for human health and the environment and they need to be treated after the renovation. Regarding the aesthetic part, the Modern Movement distanced itself from the images of the past through clear, clean, flat, sharp, and edgy facades with continuity between inside and outside. But the use of prefabricated elements in most of the office buildings gave the facade an expression of monotony, high degree of similarity between buildings and a lack of individual identity.

According to the above mentioned evaluation of the architectural quality of Danish office buildings built between 1960-1980, renovating these buildings is an important action to be taken to solve the technical problems in a sustainable way and, on the other hand, adding new aesthetic values being less fond of repetition and more fond of variety.

\section{Conclusion}

It is important to find solutions for the problems that are facing Danish office buildings built between 1960 and 1980. Renovating these buildings should be carefully achieved in an aesthetic way where taking under consideration the old style of the building and at the same time adding a new and interesting expression to the facade. Changing the window area is a sensitive subject due to its visual and optical importance and its effect on the indoor climate on one side and its impact on the expression of the facade on the other side. It is important to choose the suitable and energy efficient components, strategies and solutions for the renovation to reduce the energy consumption for heating and cooling which leads to a better impact on environment and economic advantage in the same time.

\section{References}

[1] Ministry of Building, "Energy agency," 2015. [Online]. Available: http://www.ens.dk/. [Accessed April 2015.] 
[2] W. J. R. Curtis, Modern architecture since 1900, Phaidon Press Limited, 1996.

[3] K. Dirckinck-Holmfeld, Guide to Danish Architecture 2 1960-1995, Copenhagen: Arkitektens Forlag, 1995.

[4] Susanne Mørch Flagstad, Susse Laustsen, "Kontormiljøets historiske udvikling," SBI, 1983.

[5] Bent Hindrup, Ole Kirkegård, Susanne Prag, Kontor miljø- problemer og planlægningsprincipper, SBI, 1982.

[6] Jonas Mortensen, Klaus Rovsing Kristiansen, Maria Kanstrup-Clausen, "Green and smart buildings in Denmark," Copenhagen Cleantech Cluster, Copenhagen, 2012.

[7] Anne Beim, Kasper Sanchez Vibæk, Thomas Jørgensen, “Arkitektonisk kvalitet \& industrelle byggesystemer," CINARK, 2007.

[8] Anders Dragheim, 22 Overfrakker, Boligministeriet, Bygge- og Boligstyrelsen, 1997.

[9] BYGGE- OG BOLIGSTYRELSEN, "Building regulation 1961, 1966 and 1972," Ministry of Housing, Copenhagen, 1961.

[10] 'Building regulation 2015," Energistyrelsen, 2015.

[11] Secretariat of the energy labeling scheme for vertical windows, "Energy windows," 2015. [Online]. Available: http://energivinduer.dk. [Accessed 2015.]

[12] J. E. Gram, Interviewee, VarmeIsoleringsForeningen. [Interview] April 2015.

[13] Francis Duffy, Colin Cave, Jhon Worthington, Planing office space, Nichols publishing company, 1976.

[14] P. N. Ernst Neufert, Neufert, Architects' Data, Wiley-Blackwell, 2012.

[15] Danish Working Environment Authority,, "Arbejdstilsynet," 2015. [Online]. Available: http://arbejdstilsynet.dk/da/arbejdsmiljoemner/ indeklima. [Accessed 2015.]

[16] Anne Abildgaard, “Træ er miljø,” Brancheforeningen Danske Byggecentre - Dansk Skovforening - Dansk Træforening, [Online]. Available: http://www.trae.dk/. [Accessed 2015.]

[17] L. L. N. M. Anne Beim, Økologi og Arkitektonisk Kvalitet, Arkitektskolens Forlag, 2002.

[18] J. Plante, "The problem of designing facades within an industrialized building system," Massachusetts Institute of Technology, 1985.

[19] J. Engelmark, Danish building practices "multi story buildings through 150 years", 1. edition, 2013.

[20] Ida Garre, Fremtidens kontorbyggeri, COWIfonden, 1998.

[21] Hossein Zabihi, Farah Habib, Leila Mirsaeedie, "Definitions, Concepts and New Directions in Industrialized Building Systems (IBS)," KSCE Journal of Civil Engineering, 2012. 